\title{
Krim ekstrak daun Lantana camara Linn. 4\% stabil setelah disimpan selama 1 tahun
}

\author{
Muhammad Refan Mahardhitya ${ }^{1}$ \\ Mauritius Lambertus Edy Parwanto
}

\begin{abstract}
ABSTRAK
\section{LATAR BELAKANG}

Tumbuhan mengandung metabolit sekunder yang dapat berpotensi sebagai antioksidan, diantaranya adalah alkaloid, flavonoid, senyawa fenol, steroid, dan terpenoid. Lantana camara Linn. (tembelekan) merupakan tanaman liar yang tumbuh tanpa perawatan khusus yang digunakan masyarakat secara empiris untuk mengobati beberapa macam penyakit. Penelitian ini bertujuan untuk melihat perbandingan kadar flavonoid krim ekstrak daun L. camara Linn. 3\%, 4\%, 5\% setelah disimpan selama 1 tahun.

\section{METODE}

Penelitian ini merupakan studi observasional dengan desain potong lintang yang menggunakan krim ekstrak daun L. camara Linn. 3\%, $4 \%$ dan $5 \%$. Pengukuran $\mathrm{pH}$, daya sebar dan uji organoleptik dilakukan di Laboratorium Biologi, Fakultas Kedokteran, Universitas Trisakti, sedangkan pengukuran kadar flavonoid dilakukan di Laboratorium Pengujian Penelitian Terpadu UGM. Pengukuran kadar flavonoid terhadap ketiga sampel tersebut menggunakan spektrofotometer. Data yang diperoleh diuji normalitas dan homogenitasnya. Apabila data normal dan homogen dilanjutkan dengan uji one way anova, apabila data tidak normal dan atau tidak homogen dilakukan uji Kruskall-Wallis dengan tingkat kemaknaan 0,05.
\end{abstract}

\section{HASIL}

Krim ekstrak daun L. camara Linn. 3\%, 4\% dan 5\% memiliki pH yang sama yaitu 6. Daya sebar krim ekstrak daun L. camara Linn. $3 \%$ sebesar 2.44 senti meter $(\mathrm{cm})$, sedangkan untuk krim ekstrak daun L. camara Linn. 4\% sebesar $2.12 \mathrm{~cm}$ dan krim ekstrak daun L. camara Linn. 5\% sebesar $2.29 \mathrm{~cm}$. Hasil uji organoleptik terhadap krim ekstrak daun $L$. camara Linn. 3\%, 4\% dan 5\% memperlihatkan bentuk sediaan setengah padat, warna hijau tua dan bau khas ekstrak. Setelah disimpan selama 1 tahun, perubahan kadar flavonoid pada krim ekstrak daun L. camara Linn. 3\%, 4\% dan 5\% masing-masing sebesar $+85.6 \%,-1.07 \%$ dan $+54.7 \%(\mathrm{p}=0.001)$.

\section{KESIMPULAN}

Setelah disimpan selama 1 tahun, krim ekstrak daun L. camara Linn. 3\%, $4 \%$ dan 5\% memiliki pH 6, masing-masing krim memiliki daya sebar dan organoleptik yang sama. Krim ekstrak daun $L$. camara Linn. $4 \%$ paling stabil dibanding krim ekstrak daun $L$. camara Linn. 3\% dan 5\%.

Kata kunci : Lantana camara, flavonoid, obat herbal

\author{
${ }^{1}$ Program Studi Kedokteran, \\ Fakultas Kedokteran, \\ Universitas Trisakti \\ 2 Departemen Biologi, \\ Fakultas Kedokteran, \\ Universitas Trisakti
}

\section{Korespondensi:}

Dr. Drs. Parwanto MLE, M.Biomed

Departemen Biologi,

Fakultas Kedokteran,

Universitas Trisakti. Jl. Kyai Tapa

No. 260 Grogol (Kampus B),

Jakarta Barat 11470.

email: edyparwanto@trisakti.ac.id; edy.parwanto@gmail.com

J Biomed Kes 2018;1(1):50-57

DOI: 10.18051/JBiomedKes.2018.

v1.50-57

pISSN: 2621-539X / eISSN: 2621-5470

Artikel akses terbuka (open access) ini didistribusikan di bawah lisensi Creative Commons Attribution 4.0 International (CC-BY 4.0) 


\section{ABSTRACT}

\section{Lantana camara Linn. leaf extracts cream of $4 \%$ stable after being stored for 1 year}

\section{BACKGROUND}

Plants contain secondary metabolite that potentially acts as anti-oxidant, such as alcaloid, flavonoid, phenol compunds, steroid, dan terpenoid. Lantana camara Linn. is a wild plant without special treatmens, which is generally used for empiric medicine. Objective of this study to determine the distinction of flavonoid levels in Lantana camara Linn. leaf extracts cream of 3\%, 4\%, 5\% after being stored for 1 year.

\section{METHODS}

This study was an observational study with cross sectional design using L. camara Linn. leaf extracts cream of $3 \%, 4 \%$ and $5 \%$. Measurements of $\mathrm{pH}$, scatter and organoleptic test were done at Laboratory of Biology, Faculty of Medicine, University of Trisakti. Measurement of flavonoid level was done at The Integrated Research and Testing Laboratory or Lembaga Penelitian dan Pengujian Terpadu (LPPT) University of Gajah Mada, Yogyakarta. Measurement of flavonoid levels using a spectrophotometer. The data obtained, then tested normality and homogeneity. If the data is normal and homogeneous, then continued with analysis of one way anova test, if the data is not normal and or not homogeneous then continued with analysis of Kruskall-Wallis test. We use $p$ value of 0.05 .

\section{RESULT}

L. camara Linn. leaf extracts cream of 3\%, 4\% and 5\% had the same pH ie 6. Scatter test of L. camara Linn. leaf extracts cream of $3 \%, 4 \%$ and $5 \%$ showed 2.44 centimeter $(\mathrm{cm}), 2.12 \mathrm{~cm}$ and $2.29 \mathrm{~cm}$, respectively. Organoleptic test of L. camara Linn. leaf extracts cream of 3\%, 4\% and 5\% showed semi-solid form, dark green color and specific smell of extract. After being stored for 1 year, flavonoid levels in L. camara Linn. leaf extracts cream of $3 \%, 4 \%$ and $5 \%$ were $85.6 \%,-1.07 \%$ and $+54.7 \%(\mathrm{p}=0.001)$, respectively.

\section{CONCLUSION}

After being stored for 1 year, the L. camara Linn. leaf extracts cream of 3\%, 4\% and 5\% has the same of pH ie 6 . Each cream having similar scattering and organoleptic properties. L. camara Linn. leaf extracts cream of $4 \%$ is most stable compared to L. camara Linn. leaf extracts cream of $3 \%$ and $5 \%$.

Keywords : Lantana camara, flavonoid, herbal medicine

\section{PENDAHULUAN}

Keanekaragaman jenis tumbuhan di Indonesia sangatlah beragam, maka sebaiknya kita sebagai penerus bangsa dapat memanfaatkannya sebaik mungkin untuk memenuhikeperluan manusiapada umumnya. Banyak dari tumbuhan tersebut dimanfaatkan diantaranya sebagai kebutuhan makanan dan juga pengobatan. Pemanfaatan tanaman sebagai bahan obat sedang digalakkan di Indonesia. Penggunaan obat tradisional pada masyarakat telah berlangsung lama secara turun temurun. Indonesia memiliki banyak jenis tanaman yang dapat dimanfaatkan sebagai sumber bahan obat. Tanaman liar yang tumbuh bebas di sekitar pekarangan atau di kebun bahkan mampu dimanfaatkan sebagai obat. ${ }^{1}$

Lantana camara Linn. atau biasa dikenal dengan nama tembelekan merupakan tanaman liar yang tumbuh tanpa perawatan khusus. Tumbuhan tersebut merupakan salah satu spesies potensial ditinjau dari segi budidaya sehingga akan terus dilakukan penelitian secara mendalam tentang potensi farmasi yang dimilikinya yang pada akhirnya tumbuhan tersebut nantinya menjadi suatu komoditi yang bernilai ekonomi. ${ }^{2}$

Dewasa ini mulai diteliti tentang kandungan bahan kimia dan efek farmakologi dari L. camara Linn. Tumbuhan tersebut dapat dikembangkan menjadi obat herbal. Pengetahuan tentang obat tradisional dan tanaman obat dan studi tentang prinsip kimia ilmiah dapat menuntun untuk menemukan penemuan obat baru dan lebih murah. ${ }^{3}$ Masyarakat secara empiris telah menggunakan tembelekan untuk mengobati beberapa macam penyakit seperti batuk, luka, peluruh air seni, peluruh keringat, peluruh haid, penurun panas, obat bengkak, encok dan bisul. ${ }^{4}$

Zat kimia yang dikandung oleh tembelekan diantaranya minyak atsiri, fenol, 
flavonoid, karbohidrat, protein, alkaloid, glikosida, glikosida iridoid, etanoid fenil, oligosakarida, quinin, saponin, steroid, triterpin, sesquiterpenoid dan tanin..$^{5}$ Diantara zat kimia yang dikandung oleh tembelekan, flavonoid merupakan senyawa yang terdiri atas 15 atom karbon yang umumnya juga ditemukan pada dunia tumbuhan. Zat tersebut hampir terdapat pada semua bagian tumbuhan termasuk buah, akar, daun dan kulit luar batang dan memiliki banyak fungsi. ${ }^{6}$ Hasil penelitian sebelumnya menunjukkan bahwa flavonoid merupakan metabolit skunder yang berpotensi sebagai antioksidan, seperti halnya alkaloid, fenol, steroid, dan terpenoid. $^{5}$

Telah diketahui bahwa biosintesis flavonoid terjadi di jaringan yang spesifik atau pada tahap perkembangan tumbuhan yang spesifik. ${ }^{7}$ Berbagai spesies tanaman memiliki kelenjar trikoma, yaitu sebuah struktur yang berfungsi untuk mensekresi flavonoid alami. ${ }^{8}$ Biosintesis flavonoid diregulasi oleh cahaya dan temperatur, tetapi hal ini juga tergantung dari faktor transkripsi pada tanaman dan spesies dari tanaman tersebut. ${ }^{9}$

Selain itu, kadar flavonoid juga dipengaruhi oleh adanya metabolit sekunder yang juga terkandung di dalam tanaman, dimana biosintesis metabolit sekunder diinduksi oleh jasmonate. Jasmonate dan derivatif metil-jasmonate dapat menginduksi biosintesis indol flavonoid pada kultur suspensi sel dengan auxin dan mempertahankan produksi alkaloid indol flavonoid ketika sel dikultur pada medium tanpa auxin. ${ }^{9}$ Beberapa faktor transkripsi diregulasi oleh hormon yang memberikan sinyal beruntun yang mengaktivasi transkripsi gen untuk biosintesis flavonoid. ${ }^{10}$ Sebuah studi menunjukkan bahwa pemberian metiljasmonate secara eksogen memberikan pengaruh terhadap produksi flavonoid dengan meregulasi gen terpene sintase. ${ }^{11}$ Terkadang regulasi biosintesis flavonoid juga diinduksi oleh serangan patogen atau stres abiotik. ${ }^{8}$

Flavonoid menjadi penting sebagai komponen obat herbal, oleh karena itu dalam pengembangan obat herbal yang perlu diperhatikan adalah faktor penyimpanan sediaan obat. Penyimpanan sediaan obat diduga mempengaruhi perubahan kadar flavonoid. Penelitian telah menunjukkan bahwa penyimpanan sediaan obat pada suhu rendah dapat mengurangi kegiatan respirasi dan metabolisme, memperlambat proses penuaan serta mencegah kehilangan air. ${ }^{12}$

Pengujian nilai $\mathrm{pH}$ dimaksudkan untuk membandingkan nilai $\mathrm{pH}$ krim dengan nilai $\mathrm{pH}$ kulit. Nilai $\mathrm{pH}$ krim yang dibuat harus sesuai dengan nilai $\mathrm{pH}$ kulit yaitu 4,5 s/d 6,5 agar tidak mengiritasi kulit dan nyaman digunakan. Sediaan yang baik memiliki daya sebar antara 5-7 cm. Selain itu sediaan krim juga perlu uji organoleptik. Pengamatan terhadap karakteristik sediaan yang dilakukan antara lain $\mathrm{pH}$, daya sebar, bentuk sediaan, bau dan warna sediaan. ${ }^{13}$

Berdasarkan pemaparan di atas, penelitian ingin menelusuri lebih lanjut tentang karakteristik krim ekstrak daun L.camara Linn. 3\%, 4\% dan 5\% setelah disimpan selama 1 tahun. Selain itu juga ingin diketahui tentang perbandingan kadar flavonoid krim ekstrak daun L. camara Linn. $3 \%$, 4\% dan 5\% setelah disimpan selama 1 tahun.

\section{METODE}

Penelitian ini merupakan studi observasional dengan desain potong lintang yang menggunakan krim ekstrak daun L. camara Linn. 3\%, 4\% dan 5\%. Penelitian ini bersifat deskriptif laboratorium atau mengamati dan mendeskripsikan hasil pengujian yang dilakukan. Pengujian yang dilakukan tidak mengunakan perlakuan terhadap hewan uji. Data yang diperoleh dibandingkan dengan standart yang berlaku untuk menarik kesimpulan.

Krim ekstrak daun L. camara Linn. disimpan pada suhu ruang selama 1 tahun mulai Desember 2016-November 2017 di Laboratorium Biologi, Fakultas Kedokteran Universitas Trisakti. Pengambilan sampel untuk pengukuran $\mathrm{pH}$, daya sebar dan uji organoleptik secara simple random sampling untuk memilih sampel $(n=3)$ ditentukan oleh peneliti. 
Pengukuran $\mathrm{pH}$, daya sebar dan uji organoleptik dilakukan pada bulan November 2017 di Laboratorium Biologi, Fakultas Kedokteran, Universitas Trisakti. Pengukuran pH krim ekstrak daun L. camara Linn. menggunakan alat bantu stik $\mathrm{pH}$ universal yang dicelupkan ke dalam 0.5 gram krim yang telah diencerkan dengan $5 \mathrm{ml}$ aquadest. Selanjutnya stik $\mathrm{pH}$ universal dicocokkan dengan warna indikator. Pengukuran daya sebar krim ekstrak daun L. camara Linn. dengan cara meletakkan $0,5 \mathrm{~g}$ krim diantara dua lempeng objek transparan yang diberi beban 0 gram, 50 gram dan 100 gram. Pengukuran diameter daya sebar dilakukan setelah 1 menit pemberian beban. Uji organoleptik dilakukan dengan cara melihat warna dan memmbau krim.

Pengukuran kadar flavonoid dilakukan pada bulan November 2017, di Laboratorium
Pengujian Penelitian Terpadu Universitas Gajah Mada. Pengukuran kadar flavonoid tersebut menggunakan spektrofotometer pada panjang gelombang 510 nanometer (nm). Penentuan kadar flavonoid ditentukan dengan standar equivalen quesertin.

Data yang diperoleh diuji normalitas dan homogenitasnya. Data yang normal dan homogen dilanjutkan dengan uji one way anova, sedangkan data yang tidak normal dan atau tidak homogen dilakukan uji Kruskall-Wallis dengan tingkat kemaknaan 0,05 .

\section{HASIL}

Uji $\mathrm{pH}$, daya sebar dan organoleptik krim ekstrak L. camara Linn. 3\%, 4\% dan 5\% disajikan pada tabel 1 .

Krim ekstrak daun L. camara Linn.

Tabel 1. Uji pH, daya sebar dan organoleptik krim ekstrak daun L. camara Linn. 3\%, 4\% dan 5\%

\begin{tabular}{|c|c|c|c|}
\hline Jenis uji & $\begin{array}{l}\text { Ekstrak daun } \\
\text { L. camara Linn. 3\% }\end{array}$ & $\begin{array}{l}\text { Ekstrak daun } \\
\text { L. camara Linn. } 4 \%\end{array}$ & $\begin{array}{l}\text { Ekstrak daun } \\
\text { L. camara Linn. } 5 \%\end{array}$ \\
\hline \multicolumn{4}{|c|}{ 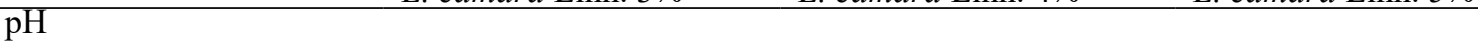 } \\
\hline -replikan 1 & 6 & 6 & 6 \\
\hline -replikan 2 & 6 & 6 & 6 \\
\hline -replikan 3 & 6 & 6 & 6 \\
\hline Rata-rata & 6 & 6 & 6 \\
\hline \multicolumn{4}{|l|}{ Daya sebar } \\
\hline beban 0 gram & 2 & 1.8 & 2 \\
\hline beban 50 gram & 2.5 & 2 & 2.3 \\
\hline beban 100 gram & 2.8 & 2.4 & 2.5 \\
\hline \multicolumn{4}{|l|}{-replikan 2} \\
\hline beban 0 gram & 2 & 1.9 & 2 \\
\hline beban 50 gram & 2.5 & 2.2 & 2.4 \\
\hline beban 100 gram & 2.9 & 2.5 & 2.5 \\
\hline \multicolumn{4}{|l|}{-replikan 3} \\
\hline beban 0 gram & 2 & 1.9 & 2 \\
\hline beban 50 gram & 2.5 & 2 & 2.4 \\
\hline beban 100 gram & 2.8 & 2.4 & 2.5 \\
\hline Rata-rata & 2.44 & 2.12 & 2.29 \\
\hline $\begin{array}{l}\text { Organoleptik } \\
\text { bentuk sediaan } \\
\text { warna } \\
\text { bau }\end{array}$ & $\begin{array}{l}\text { setengah padat } \\
\text { hijau tua } \\
\text { khas ekstrak daun } \\
\text { L.camara Linn. }\end{array}$ & $\begin{array}{l}\text { setengah padat } \\
\text { hijau tua } \\
\text { khas ekstrak daun } \\
\text { L.camara Linn. }\end{array}$ & $\begin{array}{l}\text { setengah padat } \\
\text { hijau tua } \\
\text { khas ekstrak daun } \\
\text { L.camara Linn. }\end{array}$ \\
\hline
\end{tabular}

Keterangan: $\mathrm{pH}=$ power of hydrogen; L. camara Linn.=Lantana camara Linn. 
$3 \%, 4 \%$ dan $5 \%$ memiliki $\mathrm{pH}$ yang sama yaitu 6. Rata-rata daya sebar krim ekstrak daun L. camara Linn. 3\%, 4\% dan 5\% masingmasing 2.44, 2.12 dan 2.29. Uji organoleptik krim ekstrak daun L. camara Linn. 3\%, 4\% dan 5\% memperlihatkan ciri yang sama yaitu bentuksediaan setengah padat, berwarna hijau tua dan berbau khas ekstrak daun $L$. camara Linn.

Pembuatan kurva standar kalibrasi quesertin pada panjang gelombang 510 nano meter (nm) untuk menentukan kadar flavonoid pada ekstrak daun L.camara Linn. disasjikan pada gambar 1.

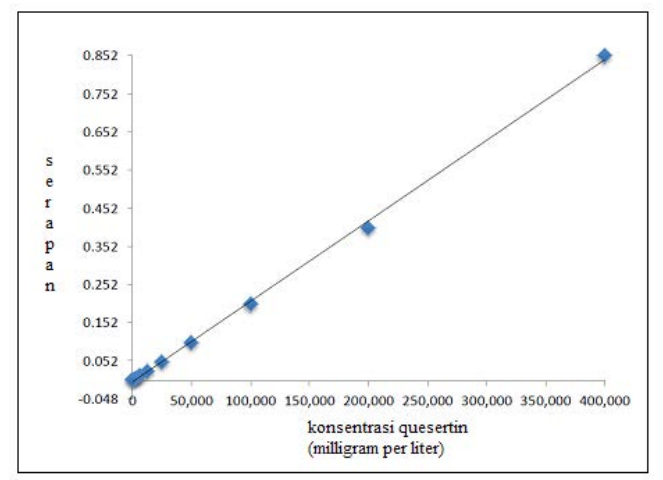

Gambar 1. Kurva standar kalibrasi quesertin.

Quercetin digunakan sebagai standar dalam penentuan flavonoid total. Kurva kalibrasi quercetin dengan persamaan $\mathrm{y}$ $=0.002 \mathrm{x}-0.006$ dengan nilai koefisien korelasinya $(r=0,995)$. Kurva ini telah berhasil membantu untuk menentukan kadar senyawa flavonoid dalam sampel krim ekstrak daun L. camara Linn. didasarkan pada persamaan garis yang didapatkan. Perbandingan kadar flavonoid krim ekstrak daun L. camara Linn. disajikan pada gambar 2 .

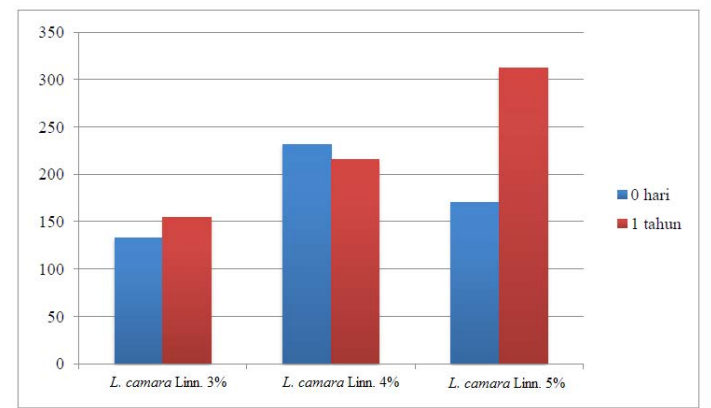

Gambar 2. Perbandingan kadar flavonoid krim ekstrak daun L. camara Linn.

Perbandingan kadar flavonoid pada krim ekstrak daun L. camara Linn. 3\%, 4\% dan 5\% sebelum dan setelah disimpan selama 1 tahun dihitung dengan rumus nilai stabilitas sama dengan kadar flavonoid kontrol dibagi dengan kadar flavonoid perlakuan dikalikan $100 \%$.

Gambar di atas menunjukkan adanya peningkatan kadar flavonoid pada krim ekstrak daun L. camara Linn. 3\% sebesar 85,6\% dan pada konsentrasi $5 \%$ adalah sebesar 54,7\%, sedangkan penurunan kadar flavonoid sebesar 1,07\% ditemukan pada krim ekstrak daun $L$. camara Linn. $4 \%$.

Hasil uji normalitas terhadap data tersebut di atas diperoleh nilai $p=0.07$ yang menandakan data terdistribusi dengan baik, tetapi uji homogenitas diperoleh nilai $\mathrm{p}=0.04$ yang berarti data tidak homogen.Hasil tranformasi juga menunjukkan bahwa data berdistribusi normal tetapi tidak homogen. Oleh karena itu dilakukan uji Kruskall-Wallis untuk melihat perbandingan kadar flavonoid krim ekstrak daun L.camara Linn. 3\%, 4\%, dan 5\% setelah disimpan selama 1 tahun.

Hasil analisis perbedaan kadar flavonoid antara krim ekstrak daun L.camara

Tabel 2. Perbedaan kadar flavonoid antara krim ekstrak daun L.camara Linn. 3\%, 4\%, dan 5\% setelah disimpan selama 1 tahun.

\begin{tabular}{lllll}
$\begin{array}{l}\text { Krim ekstrak daun } L . \\
\text { camara Linn. }\end{array}$ & $\begin{array}{l}\text { Jumlah } \\
\text { ulangan } \\
\text { (n) }\end{array}$ & $\begin{array}{l}\text { Kadar flavonoid }(\mathrm{mg} / \mathrm{L}) \\
\text { waktu penyimpanan } \\
0 \text { tahun }\end{array}$ & 1 tahun & $\begin{array}{l}\text { Tingkat } \\
\text { kemaknaan } \\
(\mathrm{p})\end{array}$ \\
\hline $3 \%$ & 6 & 132.8 & 155.12 & $0.01^{*}$ \\
$4 \%$ & 6 & 231.96 & 215.40 & 311.86 \\
\hline
\end{tabular}

Keterangan: L. camara Linn.=Lantana camara Linn.; *Uji Kruskall-Wallis 
Linn. 3\%, 4\%, dan 5\% setelah disimpan selama 1 tahun disajikan pada tabel 2.

Data pada tabel di atas memperlihatkan bahwa kadar flavonoid krim ekstrak daun L. camara Linn. 3\%, 4\%, dan 5\% setelah disimpan selama 1 tahun berbeda $(p=0.001)$.

\section{PEMBAHASAN}

Pengujian nilai $\mathrm{pH}$ dimaksud untuk membandingkan nilai $\mathrm{pH}$ krim dengan nilai $\mathrm{pH}$ kulit. Nilai $\mathrm{pH}$ krim yang dibuat harus sesuai dengan nilai $\mathrm{pH}$ kulit yaitu 4.5-6.5 agar tidak mengiritasi kulit dan nyaman digunakan. Hasil penelitian lain memperlihatkan bahwa pengujian nilai $\mathrm{pH}$ untuk salep ekstrak daun L. camara Linn. dengan konsentrasi $20 \%$ dan 24\% memenuhi parameter nilai $\mathrm{pH}$ yang dipersyaratkan. ${ }^{13}$ Kami berpendapat bahwa nilai $\mathrm{pH}$ yang stabil akan membantu menghindari atau mencegah kerusakan sediaan krim ekstrak daun L. camara Linn. selama penyimpanan atau penggunaan.

Mengacu syarat daya sebar krim yang baik, maka krim ekstrak daun L. camara Linn. 3\%, 4\% dan 5\% setelah disimpan selama 1 tahun belum memenuhi syarat sebagai krim yang kurang baik karena mempunyai daya sebar kurang dari $5 \mathrm{~cm}$. Pedoman sediaan krim yang baik yaitu sediaan krim yang jika dioleskan akan menyebar dan nyaman digunakan. Sediaan tersebut memiliki daya sebar 5-7 cm. ${ }^{14,15}$ Berdasar hasil uji daya sebar krim ekstrak daun L. camara Linn. 3\%, 4\% dan 5\% setelah disimpan selama 1 tahun masih bisa digunakan akan tetapi menimbulkan rasa yang kurang nyaman karena akan terasa tebal di kulit. Hasil serupa diperoleh bahwa salep ekstrak daun L. camara Linn. $20 \%$ dan $24 \%$ juga belum memenuhi syarat daya sebar yang baik. Meskipun demikian, salep ekstrak daun $L$. camara Linn. $20 \%$ dan $24 \%$ memenuhi syarat tentang homogenitas sediaan, hal ini berarti bahwa sediaan bersifat homogen atau tercampur merata antara zat aktif dengan basis salep. ${ }^{13}$

Pada uji organoleptik, krim ekstrak daun L. camara Linn. 3\%, 4\%, 5\% setelah disimpan selama 1 tahun masih memenuhi syarat yang baik. Pengamatan yang dilakukan dalam uji ini adalah bentuk sediaan, bau dan warna sediaan. Parameter kualitas salep yang baik adalah bentuk sediaan setengah padat, salep berbau khas ekstrak yang digunakan dan berwarna seperti ekstrak. Hasil penelitian ini sesuai dengan penelitian sebelumnya yang menguji salep ekstrak daun $L$. camara Linn. 20\% dan 24\% memenuhi kriteria uji organoleptik. ${ }^{13}$

Berdasarkan hasil penelitian dengan menggunakan uji stabilitas, diperoleh hasil yang menunjukkan perbandingan stabilitas kadar flavonoid pada krim ekstrak daun $L$. camara Linn. 3\%, 4\%, 5\% setelah disimpan selama 1 tahun. Kadar flavonoid pada krim ekstrak daun L. camara Linn. 3\% mengalami peningkatan sebesar $85,6 \%$ dan peningkatan sebesar $54,7 \%$ terdapat pada krim ekstrak daun L. camara Linn.5\%. Sebaliknya, kadar flavonoid krim ekstrak daun L. camara Linn. 4\% mengalami penurunan sebesar 1,07\% setelah disimpan selama 1 tahun. Stabilitas obat dapat terbilang baik jika perubahan kadar di dalam obat tersebut kurang dari 10\%. Pada penelitian ini didapatkan hasil bahwa krim ekstrak daun L. camara Linn. 4\% memiliki stabilitas yang baik. Oleh karena itu ekstrak daun L. camara Linn. 4\% terbilang aman meskipun sudah disimpan selama 1 tahun. Berdasar data bahwa krim ekstrak daun $L$. camara Linn. kadar 4\% lebih stabil dibanding kadar 5\%, hal ini sesuai dengan penelitian sebelumnya yang memperlihatkan bahwa ekstrak daun L. camara Linn. yang dikandung dalam salep 5\% lebih bagus pengaruhnya terhadap penyembuhan luka kulit tikus dibanding salep ekstrak daun L. camara Linn. $10 \% .^{16}$

Berdasarkan deskripsi di atas, dapat dijelaskan faktor eksternalyangmempengaruhi kadar flavonoid pada krim ekstrak daun L. camara Linn. Kondisi eksternal seperti berapa lama penyimpanan krim eksrak daun L. camara Linn. yang mampu memberikan perbedaan kadar flavonoid pada krim yang sudah disimpan selama 1 tahun. Faktor eksternal lain yang mempengaruhi kadar flavonoid adalah cahaya dan suhu di tempat 
penyimpanan krim ekstrak daun L. camara Linn. Selain faktor eksternal tentunya faktor internal juga ikut mempengaruhi stabilitas krim ekstrak daun L. camara Linn. misalnya kandungan zat dalam bahan yang akan dibuat ekstrak. Oleh karena itu diperlukan penelitian lebih lanjut untuk mengetahui faktor internal maupun eksternal yang menyebabkan penurunan kadar flavonoid pada krim ekstrak daun L. camara Linn.

Keterbatasan yang terdapat pada penelitian ini adalah faktor-faktor yang mempengaruhi kadar flavonoid pada krim ekstrak L. camara Linn. 3\%, 4\% dan 5\% setelah disimpan selama 1 tahun tidak diukur sebagai variabel bebas dalam penelitian ini. Oleh karena itu masih perlu penelitian tentang faktor-faktor yang mempengaruhi perubahan kadar flavonoid pada krim tersebut.

\section{KESIMPULAN}

Berdasarkan hasil penelitian tersebut diatas, maka dapat disimpulkan bahwa krim ekstrak daun L. camara Linn. 3\%, 4\%, dan 5\% yang disimpan selama 1 tahun memiliki nilai $\mathrm{pH}$ dan sifat organoleptik yang baik, meskipun daya sebarnya belum memenuhi syarat sediaan yang baik. Selama 1 tahun penyimpanan, krim ekstrak daun L. camara Linn. 4\% paling stabil dibanding 3\% dan 5\%.

\section{SARAN}

Sebaiknya dilakukan penelitian tentang faktor internal yang mempengaruhi stabilitas krim ekstrak daun L. camara Linn. sebagai syarat awal dalam pembuatan sediaan.

\section{UCAPAN TERIMA KASIH}

Ucapan terima kasih disampaikan kepada Dekan Fakultas Kedokteran, Universitas Trisakti yang memberikan izin untuk terlaksananya penelitian ini. Ucapan terima kasih juga disampaikan kepada Pimpinan LPPT UGM sehingga penelitian ini dapat terlaksana.

\section{DAFTAR REFERENSI}

1. Pakaya W, Ischak NI, Tangio JS. Analisis Kadar Flavonoid Dari Ekstrak Metanol Daun dan Bunga Tembelekan. Jurusan Pendidikan Kimia Fakultas Matematika dan IPA Universitas Negeri Gorontalo, Jurnal Penelitian 2015:1-11.

2. Rijai L. Potensi Tumbuhan Tembelekan (Lantana camara Linn) Sebagai Sumber Bahan Farmasi Potensial. J. Trop. Pharm. Chem. 2014, 2(4):203-11.

3. Kalita S, Kumar G, Karthik L, Rao $\mathrm{KV}$. A review on medicinal properties of Lantana camara Linn. Research Journal of Pharmacy and Technology. 2012,5(6):711-15.

4. Mangela O, Ridhay A, Musafira M. Kajian aktivitas antioksidan ekstrak daun tembelekan (lantana camara 1) berdasarkan tingkat kepolaran pelarut. KOVALEN, 2016, 2(3):16-23.

5. Venkatachalam T, Kumar VK, Selvi PK, et al. Physicochemical and preliminary phytochemical studies on the Lantana Camara (L.) fruits. International Journal of Pharmacy and Pharmaceutical Sciences. 2011;3(1):52-4.

6. Lumbessy M, Abidjulu J, Paendong JJ. Uji Total Flavonoid Pada Beberapa Tanaman Obat Tradisional Di Desa Waitina Kecamatan Mangoli Timur Kabupaten Kepulauan Sula Provinsi Maluku Utara. Jurnal Mipa Unsrat Online. 2013 Jan 31;2(1):50-5.

7. Xi Z, Bradley RK, Wurdack KJ, et al. Horizontal transfer of expressed genes in a parasitic flowering plant. BMC Genomics. 2012,13:227:1-8. http://www.biomedcentral.com/14712164/13/227.

8. Lange BM dan Turner GW. Terpenoid biosynthesis in trichomes--current status and future opportunities. Plant Biotechnol J. 2013; 11(1):2-22.

9. Vranova E, Coman D, dan Guissem W. Structure and dynamics of the isoprenoid pathway network. Mol Plant. 
2012; 5(2):318-33.

10. Prins CL, Vieira IJC, Frietas SP. Growth regulators and essential oil production. Braz J Plant Physiol. 2010;22:91-102.

11. Nagegowda DA. Plant volatile terpenoid metabolism: biosynthetic genes, transcriptional regulation and subcellular compartmentation. FEBS Left. 2010; 584(14):2965-73.

12. Safaryani N, Haryanti S, Hastuti ED. Pengaruh suhu dan lama penyimpanan terhadap penurunan kadar vitamin $\mathrm{C}$ Brokoli (Brassica oleracea L). Buletin Anatomi dan Fisiologi 2007, 25(2):3945.

13. Parwanto MLE, Senjaya H, Edy HJ. Formulasi Salep Antibakteri Ekstrak Etanol Daun Tembelekan (lantana camara L). Pharmacon. 2013 Jan 8;2(3):105-8.

14. Sumarlin LO, Suprayogi A, Rahminiwati $M$, et al. Bioaktivitas ekstrak metanol daun namnam serta kombinasinya dengan madu trigona. Journal of Food Technology \& Industry/ Jurnal Teknologi \& Industri Pangan. 2015, 26(2):144-54.

15. E Hawaiz F, K Samad M. Synthesis and Spectroscopic Characterization of Some New Biological Active Azo-Pyrazoline Derivatives. Journal of Chemistry. 2012, 3;9(3):1613-22.

16. Parwanto MLE. Efficcacy of Lantana camara Linn. leaf extracts ointment on dermal wound healing were infected with Staphylococcus epidermidis. Int J Basic Clin Pharmacol 2017;6:503-10. 